\title{
Peningkatan Kemampuan Pemahaman Konsep Himpunan Melalui Pembelajaran Matematika dengan Media Articulate Studio'13
}

\author{
Farida $^{1}$, Suherman ${ }^{2}$, Sofwan Zulfikar ${ }^{3}$ \\ ${ }^{1,2,3}$ Program Studi Pendidikan Matematika UIN Raden Intan Lampung \\ zulsofwan@gmail.com
}

\begin{abstract}
The purpose of this study was to produce media products based on articulate Studio'13 in mathematics subjects that were appropriate, interesting and effective in learning. This research is a type of research and development $(R \& D)$ by modifying 10 stages into 7 stages, namely; potential and problems, information collection, product design, design validation, design revisions, product trials, and product revisions. Assessment of media feasibility is carried out by material experts and media experts. Assessment and attractiveness of students. The effectiveness of the product is seen as a percentage $>75 \%$ of the number of students who passed the KKM. This research resulted in Articulate Studio '13 learning media proven to be valid and feasible to be used as learning media after getting a score of $88.3 \%$ from 3 material experts, and a value of $86.1 \%$ from 3 media experts. For attractiveness assessments get the criteria "very feasible" based on small-scale trials that get an assessment of 77\%, and large-scale trials get a value of $80 \%$. After the final assessment was made it was stated that $79.17 \%$ of students passed the KKM than the media was declared effective. So that it can be concluded that the development of learning media has carried out is deemed feasible, interesting, and effective to use in learning.
\end{abstract}

Keyword

: Articulate Studio'13; Universal Set; Instructional Media

\begin{abstract}
Abstrak
Tujuan penelitian ini adalah untuk menghasilkan produk media pembelajaran berbasis articulate studio'13 pada mata pelajaran matematika materi himpunan yang layak, menarik, serta efektif dalam pembelajaran. Penelitian ini merupakan jenis penelitian dan pengembangan (R\&dD dengan memodifikasi 10 tahapan yang ada menjadi 7 tahapan yaitu; potensi dan masalah, pengumpulan informasi, desain produk, validasi desain, revisi desain, uji coba produk, dan revisi produk. Peniliaian kelayakan media dilakukan oleh ahli materi dan ahli media. Penilaian kemudahan dan kemenarikan dilakukan oleh peserta didik. Keefektifan produk dilihat persentase $>75 \%$ jumlah peserta didik yang lulus KKM. Penilitian ini menghasilhan media pembelajaran articulate studio'13 terbukti valid dan layak digunakan sebagai media pembelajaran setelah mendapatkan nilai sebesar $88,3 \%$ dari 3 ahli materi, dan nilai sebesar $86,1 \%$ dari 3 ahli media. Untuk penilaikan kemenarikan mendapatkan kriteria "sangat layak" berdasarkan uji coba skala kecil yang mendapatkan penilaian sebesar $77 \%$, dan uji coba skala besar mendapatkan nilai sebesar $80 \%$. Setelah dilakukan penilaian akhir dinyatakn bahawa 79,17 \% peserta didik lulus kkm dengan demikian media dinyatakan efektif. Sehingga dapat disimpulkan pengembangan media pembelajaran yang dilakukan dinyatkan layak, menarik, dan efektif digunakan dalam pembelajaran.
\end{abstract}

Kata Kunci : Articulate Studio'13; Himpunan; Media Pembelajaran

\section{Pendahuluan}

Pendidikan yang baik di suatu negara akan berdampak pada peningkatan kualitas manusianya, sehingga akan mudah di temukan masyarakat yang berkompeten di berbagai bidang. Proses pendidikan tidak dapat dipisahkan dari proses pembelajaran. Menurut Syazali, Prespektif mengajar dilakukan oleh guru/pendidik, ataupun pihak yang mendidik. Sedangkan menurut widiawati selain itu perubahan sikap dan tingkah juga akan dipengaruhi oleh pendidikan dalam usaha mendewasakan diri (Masykur, Nofrizal, and Syazali 2017).

Untuk menunjang keprofesionalan guru dalam menjalankan tugasnya, guru mempunyai kewajiban untuk turut serta dalam pelaksanaan inovasi-inovasi dalam pembelajaran. Inovasi dalam pembelajaran dapat dilakukan dengan mengembangkan model, media ataupun perangkat pembelajaran (Wijayanti and Sungkono 2017). 
Kemajuan teknologi informasi dan komunikasi seharusnya mampu memberikan pengarus positif terhadap dunia pendidikan, jika dimanfaatkan dengan baik. Khususnya teknologi komputer dan teknologi internet, baik dalam perangkat keras maupun perangkat lunak, memberikan banyak tawaran dan pilihan bagi dunia pendidikan dalam menunjang proses pembelajaran. Keunggulan yang ditawarkan bukan saja terletak pada faktor kecepatan untuk mendapatkan informasi namun juga fasilitas multimedia yang dapat membuat belajar lebih menarik, visual dan interaktif (Achadiyah n.d.). Analisis terhadap 20 penelitian yang dilakukan oleh Zakaria dan Khalid (2016) ditentukan bahwa manfaat memasukkan Perkembangan Teknologi ke dalam pengajaran matematika sangat banyak. Di antara keuntungannya adalah dari penerapan dari Virtual Learning Environment (VLE) dimana VLE dapat meningkatkan minat siswa dalam belajar matematika, meningkatkan akademik kinerja, mempromosikan pembelajaran permanen, memungkinkan interaksi positif hubungan dan mendukung pembelajaran konstruktivis (Navarro-ibarra, Cuevas, and Xochitl 2017).

Pendidik harus mampu berinovasi memberikan bahan ajar yang mudah diterima oleh peserta didik. Guru matematika memiliki kecenderungan hanya berfokus pada buku teks dan terbiasa menggunakan pelajaran menyajikan materi pembelajaran, memberi contoh masalah dan bertanya, siswa melakukan latihan pertanyaan yang terkandung dalam buku teks yang mereka gunakan dalam mengajar dan kemudian diskusikan dengan siswa (Pardimin and Widodo 2017).

Peserta didik dapat mengetahui materi tersebut tidak hanya terbatas pada tahap ingatan saja tanpa pengertian (rote learning) tetapi bahan pelajaran dapat diserap secara bermakna (meaning learning) (Farida 2015). Para ilmuwan pendidikan telah menunjukkan bahwa orang-orang di abad ke-21 membutuhkan lima kelompok keterampilan (Kemitraan untuk Keahlian Abad 21, 2008). Selain "pengetahuan tentang mata pelajaran inti" (bahasa Inggris, matematika, sains, sejarah, dan ekonomi), "keterampilan hidup dan karir," dan "dan isu isu abad kedua puluh satu "(kesadaran global, keuangan, bisnis dan literasi kewirausahaan, dan melek huruf kewarganegaraan), mereka membutuhkan dua hal lagi: "informasi, media, dan ketrampilan teknologi" (melek informasi, melek media, dan TIK) dan "keterampilan belajar dan inovasi" (keterampilan kreativitas dan inovasi, berpikir kritis dan keterampilan memecahkan masalah, dan keterampilan komunikasi dan kolaborasi)(Lee 2016). Salah satu cara dalam pemanfaatan kemajuan teknologi dalam pendidikan adalah dengan memanfaatkan perangkat lunak (Software) yang sudah ada yang bisa menunjang proses pembelajaran. Software tersebut harus disesuaikan dengan kebutuhan peserta didik, dimana disetiap kegiatan pembelajaran didalamnya dihubungkan dengan link-link sebagai navigasi yang membuat peserta didik menjadi lebih interaktif dengan program, dilengkapi dengan penyajian video tutorial, animasi dan audio untuk memperkaya pengalaman belajar.

Matematika adalah disiplin ilmu yang telah dipelajari semenjak pendidikan dasar dan membantu perkembangan disiplin ilmu lain seperti fisika, kimia, biologi, ekomomi dan lainya (Anggoro 2015). Sesuai dengan tujuan pembelajaran matematika jenjang pendidikan dasar dan pendidikan menengah adalah untuk mempersiapkan peserta didik agar dalam dunia pendidikan dapat selalu berkembang secara logis, rasional, kritis,cermat, jujur, efisien dan efektif (Syazali, 2015). Dalam memanfaatkan kemajuan teknologi, pembelajaran matematika juga harus mampu menarik perhatian peserta didik dan juga mampu memberikan pehaman konsep yang benar. Peserta didik dianggap paham dalam pemahaman konsep matematis ketika ia mampu menjelaskan konsep matematika dalam bentuk lain yang lebih sederhana, maka ia mampu menghubungkan secara logis antara fakta dan berbeda konsep dan ia bisa mengenali hubungan antara konsep baru dengan konsep sebelumnya akan saat mendukung untuk memahami konsep berikutnya(Fataturrohmah and Masykur 2017)

Berdasarkan hasil observasi di SMP N 1 Rajabasa, Kabupaten Lampung Selatan, banyak siswa yang kurang tertarik dengan pelajaran Matematika yang di sampaikan oleh guru, karena biasanya guru hanya menjelaskan materi yang ada di buku. Sementara itu sekolah sebenarnya sudah mempunyai fasilitas yang cukup untuk penggunan media elektronik dalam proses pembelajaran. Seharusnya guru bisa memanfaatkan fasilitas tersebut agar mampu meningkatkan minat siswa dalam belajar. Selanjutnya peneliti melakukan observasi di SMP N 2 Kalianda mendapatkan bahwa pada pembelajaran matematika siswa menginginkan pembelajaran yang disesuaikan dengan 
kemajuan teknologi, karena hampir seluruh siswa sudah cukup mahir mengoprasikan komputer dan sebagian peserta didik mempunyai laptop. Disisi lain berdasarkan wawancara dengan Anhar S.Pd selaku guru matematika menerangkan bahwa pemahaman konsep tentang materi himpunan oleh peserta didik sangat lemah, karena kurang pemahaman peserta didik dalam perhitungan dasar yang di gunakan dalam materi himpunan. Oleh karena itu guru seharusnya tidak lagi hanya berpatokan kepada bahan ajar dan media konvensional dalam mengajar. Bahan ajar yang digunakan adalah buku ajar, LKS dan modul cetak. Guru perlu mengembangkan bahan pembelajaran yang menarik untuk menunjang pembelajaran sehingga mampu meningkatkan pemahaman konsep tentang materi himpunan.

Pada observasi yang dilakukan di kedua sekolah, di dapatkan bahwa secara umum kedua sekolah tersebut sudah mempunyai fasilitas pembelajaran yang cukup baik. Dianataranya adalah tersedianya lab komputer, LCD Proyektor, guru yang sudah mengerti penggunaan laptop, serta ada sebagian dari peserta didik yang mempunya komputer/Laptop. Namun fasilitas yang ada di dua sekolah tersebut ternyata belum mampu di manfaatkan untuk memberikan pembelajaran matematika yang menarik bagi peserta didik.

Saat ini banyak software yang bisa digunakan sebagai software pengembang bahan ajar dan media pembelajaran yang berbasis multimedia yang bisa dimanfaatkan guru untuk mengembangkan media pembelajraan yang menarik. Salah satu dari sekian banyak softwere tersebut adalah Articulate Studio'13. Articulate merupakan software Mix Programing Tools yang dapat membantu para designer pembelajaran dari tingkat pemula hingga tingkat expert. Program Articulate memiliki kelebihan yaitu smart brainwere yang sederhana dengan prosedural tutorial interaktif melalui template yang dapat di publish secara offline maupun online sehingga memudahkan user memformatnya dalam bentuk web personal, $\mathrm{CD}$, word prosessing dan Learning Manajemen System (LMS).

Sebelumnya sudah pernah dilakukan penilitian yang membahas tentang Articulate Studio '13. Diantaranya adalah penelitian yang dilakukan oleh irwandani, tujuan dari penelitian yang dilakukan irwandani untuk menghasilkan produk modul digital interaktif berbasis Articulate Studio'13 pada mata pelajaran fisika materi gerak melingkar yang berkualitas dan menarik. Dalam penelitian ini produk Articulate Studio'13 "sangat layak" dan "sangat menarik" dan dapat digunakan sebagai modul pembelajaran.

Sedikit berbeda dengan penelitian yang di lakukan oleh irwandani dkk, pada penelitian kali ini penulis juga akan menambahkan peningkatan kemampuan belajar peserta didik dengan menggunakan Articulate Studio'13. Berdasarkan hal tersebut maka penelitian dan pengembangan tentang "Peningkatan Kemampuan Pemahaman Konsep Himpunan Melalui Pembelajaran Matematika dengan Media Articulate Studio'13 " perlu dan menarik untuk dilakukan.

\section{Metode}

Penelitian ini menggunakan metode penelitian dan pengembangan (Research and and Development), langkah-langkahnya meliputi: 1) Potensi dan masalah, 2) Pengumpulan data, 3) Desain produk, 4) Validasi desain, 5) Revisi desain, 6) Uji coba produk, 7) Revisi Produk, 8) Uji coba Pemakaian, 9) Revisi produk, 10) Produksi massal (Sugiono, 2011).

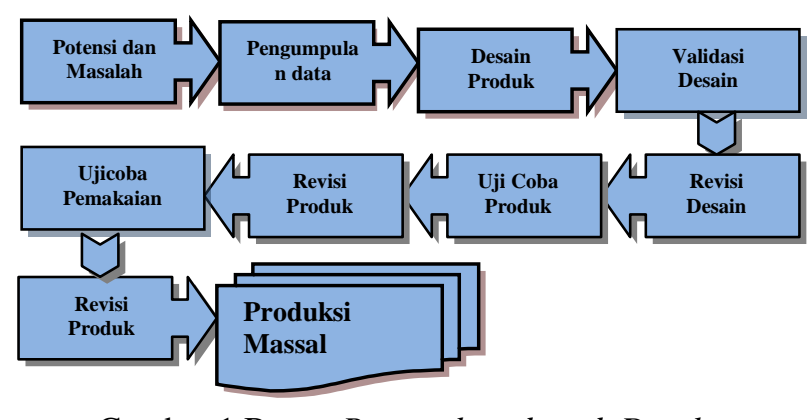

Gambar 1 Bagan Research and and Development 
Berdasarkan analisis kebutuhan dan tujuan penelitian, pada penelitian ini melihat kevalidan produk yang dikembangkan, serta untuk melihat keefektifitasan produk maka peneliti membatasi langkah penelitian dan pengembangan dari (10) sepuluh langkah menjadi (7) tujuh langkah, senada dengan penelitian sebelumnya (Irwandani, Latifah,Asyhar,Muzannur,\&Widayanti,2017). Ketujuh tahapan penelitian tersebut adalah sebagai berikut:

1. Potensi dan Masalah

2. Pengumpulan Data

3. Desain Produk

4. Validasi Desain

5. Revisi Desain

6. Uji Coba Produk

7. Revisi Produk

Instrumen yang digunakan dalam penelitian ini adalah lembar validasi berupa angket dengan menggunakan skala likert. Lembar validasi pada penelitian ini terdiri atas dari lembar validasi materi, dan lembar angket uji coba kemenarikan untuk peserta didik. Teknik analisis data sebagai berikut :

a. Penilaian angket

Tabel 1. Aturan Pemberian Skor

\begin{tabular}{ccc}
\hline No & Kategori & Skor \\
\hline 1 & Sangat Baik & 5 \\
2 & Baik & 4 \\
3 & Cukup & 3 \\
4 & Kurang & 2 \\
5 & Sangat Kurang & 1 \\
\hline
\end{tabular}

b. Menghitung persentase kelayakan dari setiap setiap aspek

$$
x_{i}=\frac{\sum S}{S_{\max }} x 100 \%
$$

Keterangan:

$\mathrm{S}_{\max }=$ Skor maksimal

$\sum S=$ Jumlah skor

$x_{i}=$ Nilai kelayakan angket tiap aspek 2013)):

c. Menghitung persentase rata-rata seluruh responden (purwanti dalam (Indrawati,

$$
\bar{x}=\frac{\sum_{i=1}^{n} \quad x_{i}}{n}
$$

Keterangan:

$x=$ Nilai rata-rata

$x_{i}=$ Nilai kelayakan angket tiap aspek

$\mathrm{n}$ = Banyaknya pernyataan

d. Mengubah skor rata-rata yang diperoleh menjadi nilai kualitatif yang sesuai dengan kriteria penilaian 
Tabel 2. Skala Kelayakan

\begin{tabular}{cc}
\hline Persentase $(\%)$ & Kriteria \\
\hline $0 \leq x \leq 25$ & Sangat Kurang Layak \\
$25<x \leq 41$ & Kurang Layak \\
$41<x \leq 50$ & Cukup Layak \\
$50<x \leq 75$ & Layak \\
$75<x \leq 100$ & Sangat Layak
\end{tabular}

Selanjutnya untuk mengetahui peningkatan pemahaman konsep peserta didik setelah menggunakan produk, didapatkan dari nilai akhir peserta didik. Menurut ahmad muhli apabila 75\% peserta didik mecapai taraf keberhasilan minimal maka pembelajaran dikatan efektif. Pada penelitian ini indikator keberhasilan. (IK) peserta didik di ambil dari nilai akhir yanga diujikan peneliti. Jadi penggunaan produk dikatakan efektif apabila IK $>75 \%$. Untuk mengetahui besaran IK digunakan rumus sebagai berikut:

$$
\begin{aligned}
& \text { IK }=\frac{\mathrm{L}}{\mathrm{N}} \times 100 \% \\
& \text { Dengan: } \\
& \mathrm{IK}=\text { Indikator Keberhasilan } \\
& \mathrm{L}=\text { Jumlah Peserta Didik mencapai KKM atau lebih } \\
& \mathrm{N}=\text { Jumlah Seluruh Peserta didik }
\end{aligned}
$$

\section{Hasil dan Pembahasan}

Hasil utama dari penelitian ini adalah media pembelajaran matematika berbasis Articulate Studio'13 dalam materi himpunan. Berdasarkan penelitian yang sudah dilaksanakan, di peroleh hasil sebagai berikut:

A. Hasil setiap langkah $R \& D$

1) Potensi dan Masalah

Penelitian dimulai dengan melakukan identifikasi potensi dan masalah ditempat penelitian. Berdasarkan identifikasi potensi dan masalah yang dilakukan melalui wawancara terhadap peserta didik dan guru, didapatkan bahwa minat peserta didik terhadap pelajaran matematika masih sangat rendah. Itu dikarenakan pembelajaran matematika dianggap sangat sulit dimengerti serta proses pembelajaran yang di anggap peserta didik terlalu monoton, karena masih terlalu bergantung dengan buku ataupun modul cetak. Disisi lain sarana dan prasana yang dimiliki sekolah maupun yang dimiliki peserta didik sudah mampu untuk menggunakan media pembelajaran yang berbasis komputer.

2) Pengumpulan Data

Setelah didapatkan potensi dan masalah di tempat penelitian. Penulis melakukan pengumpulan data-data yang dasarkan dengan kebutuhan peserta didik dan materi yang akan di pelajari disesuaikan kurikulum yang berlaku. Setelah mendapatkan data-data yang di butuhkan proses selanjutnya adalah mendesain produk. Produk didesain menggunakan software Articulate Studio'13 dengan dibantu oleh perangkat komputer lain yang di butuhkan.

3) Desain Produk

Pada tahapan desain produk ini masalah utamanya adalah masih sulitnya mendapatkan Installer software Articulate Studio'13 itu sendiri dan minimnya literatur yang menjelaskan tentang penggunaan Articulate Studio'13. Namun permasalahan untuk mendapatkan Installer software Articulate Studio'13 bisa diselesaikan dengan mendapatkan produk tersebut dari orang yang telah melakukan penelitian yang sama. Untuk literatur penggunaan Articulate Studio'13 penulis lebih banyak menonton tanyakan di channel youtube, dan berbagi informasi dengan peneliti orang yang telah melakukan penelitian yang sama. 
4) Validasi Desain

Setelah produk selesai di desain tahapan selanjutnya adalah validasi untuk menentukan kelayakan produk. Pada tahapan validasi dilakukan oleh 6 orang validator yang terdiri dari 3 orang ahli materi dan 3 orang ahli media. Pada tahap ini masing-masing ahli melakukan dua kali validasi. Permasalahan dari validasi pertama adalah masih minimnya referensi materi yang digunakan oleh penulis serta desain yang masih terlihat sangat sederhana. Meskipun pada validasi pertama produk sudah mendapatkan kriteria "layak", namun dengan masukan dari para ahli produk di perbaiki dan selanjutnya divalidasi kembali. Pada validasi yang kedua, produk mendapatkan kriteria "sangat layak" dan bisa dilanjutkan ketahapan penelitian selanjutnya. Berikut hasil validasi para ahli :

\begin{tabular}{cccccc}
\multicolumn{1}{c}{ Tabel 3. Hasil Validasi Ahli Materi } & & N Max & $(\%)$ \\
\hline No & Komponen & Butir & N & 180 & 91,1 \\
1 & Kelayakan Isi & 1 s.d 12 & 164 & 165 & 85,5 \\
\hline & Kelayakan Penyajian & 13 s.d 23 & 141 & 165 & 88,3 \\
\hline
\end{tabular}

Tabel 4. Hasil Validasi Ahli Media

\begin{tabular}{cccccc}
\hline No & Komponen & Butir & N & N Max & $(\%)$ \\
\hline 1 & Ukuran & 1 s.d 2 & 25 & 30 & 83,3 \\
2 & Desain Sampul Modul (Cover) & 3 s.d 7b & 92 & 105 & 87,6 \\
3 & Desain Isi & 8 a s.d 13c & 210 & 240 & 87,5 \\
\hline
\end{tabular}

Hal ini sejalan dengan penelitian sebelumnya yang dilakukan oleh irwandani dalam penelitian yang berjudul 'Modul Digital Interaktif Berbasis Articulate Studio'13: Pengembangan Pada Materi Gerak Melingkar Kelas X" yang mendapatkan kriteria "sangat layak" dan "sangat menarik (Irwandani et al. 2017).

5) Revisi Desain

Setelah validasi selesai, desain produk kemudian direvisi sesuai dengan masukan para ahli. Masukan ahli materi adalah : a) Pembahasan materi dilengkapi; b) Tambahkan contoh soal dari UN; c) Tambahkan refrensi materi dari banyak buku. Masukan ahli media adalah: a) Ukuran video diperbesar; b) Gunakan warna yang lebih halus.

6) Ujicoba Produk

Setelah desain direvisi, tahap selanjutnya adalah melakukan uji coba produk. Uji coba skala kecil dilakukan kepada 10 orang peserta didik kelas VII SMPN 2 Kalianda Lampung Selatan dengan memberikan angket kuisioner untuk menilai kemenarikan produk. Hasil yang didapatkan dari ujicoba skala kecil bahwa produk dinyatkan "menarik" dengan penilaian sebeser $77 \%$. Selanjutnya peniliti melakukan ujicoba sekala besar dengan responden sebanyak 24 orang peserta didik yang diberikan angket kuisoner tentang kemenarikan produk. Ujicoba skala besar mendapatkan penliain sebesar 83,4 \% dan dinyatkan "Sangat menarik". Dari hasil ujicoba produk didapatkan bahwa penilaian ujicoba skala besar menagalami peningkatan dari ujicoba skala kecil. Berikut adalah hasil dari ujicoba produk:

Tabel 5. Hasil Uji Coba Skala Kecil

\begin{tabular}{cccccc}
\hline No & Komponen & Butir & N & N Max & $(\%)$ \\
\hline 1 & Kemenarikan & 1 s.d 9 & 337 & 450 & 74,9 \\
2 & Kemudahan & 10 s.d 16 & 277 & 350 & 79,1 \\
\hline & & Rat-rata Akhir & & 77
\end{tabular}


Tabel 6. Hasil Uji Coba Skala Besar

\begin{tabular}{cccccc}
\hline \multirow{2}{*}{ No } & Komponen & Butir & N & N Max & (\%) \\
& & 1 s.d 9 & 164 & 180 & 91,1 \\
\hline 1 & Kemenarikan & 10 s.d 16 & 141 & 165 & 85,5 \\
\hline & Kemudahan & Rat-rata Akhir & & 80 \\
\hline
\end{tabular}

7. Revisi Produk

Setelah desain produk di validasi oleh ahli materi dan ahli media, serta telah di uji cobakan terhapat peserta didik dan pendidik maka diketahui kekurangan dari media produk ini. Kekurangan tersebut kemudian di perbaiki untuk mendapatkan produk yang lebih baik. Adapun revisi dari produk setelah dilakukan uji coba produk adalah penambahan daftar istilah agar peserta didik lebih mudah memahami istilah-istilah yang ada didalam media. Selain itu di tambahkan juga rangkuman materi dan daftar pustaka di bagian akhir media.

8. Produk Akhir

Adapun produk akhir dari media yang di kembangkan bisa dilihat pada gambar-gambar berikut ini:

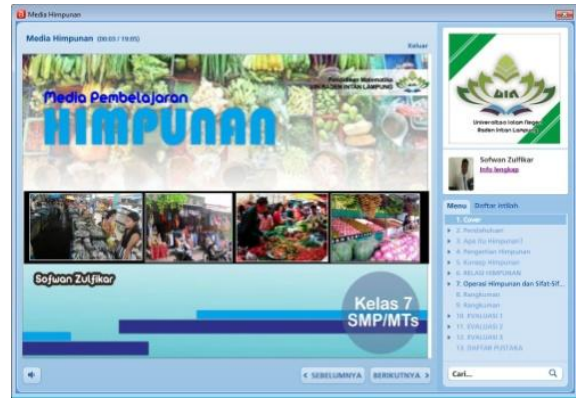

Gambar 2. Cover

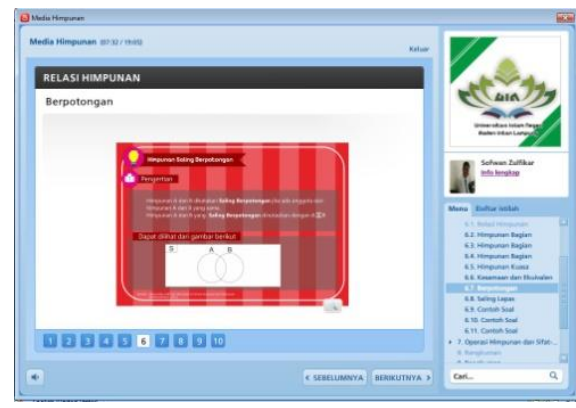

Gambar 4. Mareri

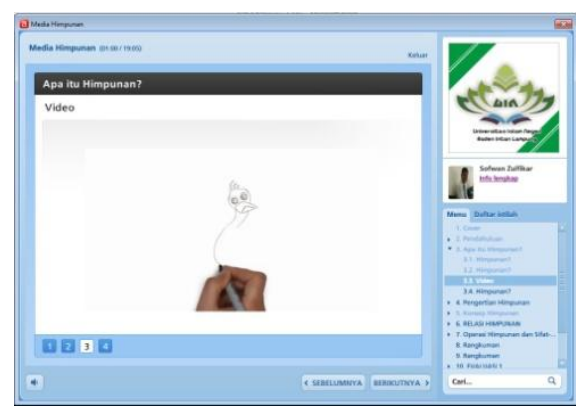

Gambar 6. Video Pembelajaran

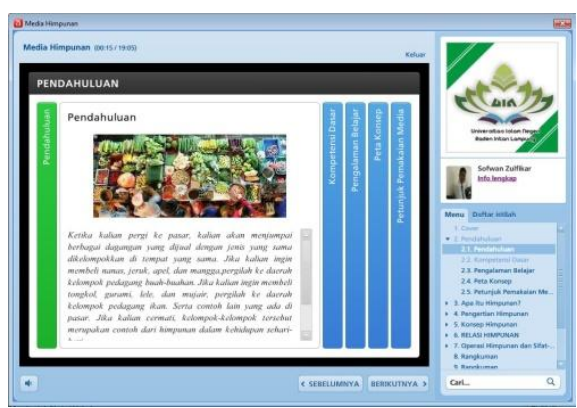

Gambar 3. Pendahuluan

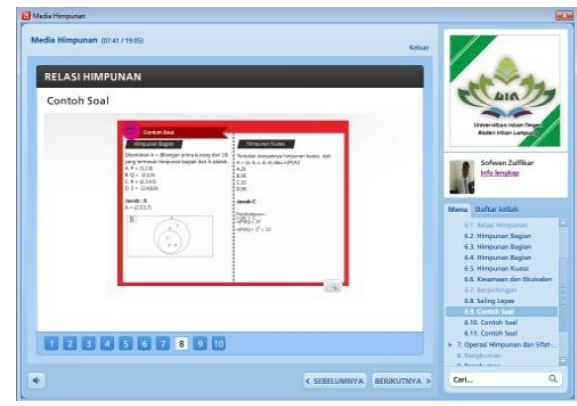

Gambar 5. Contoh Soal

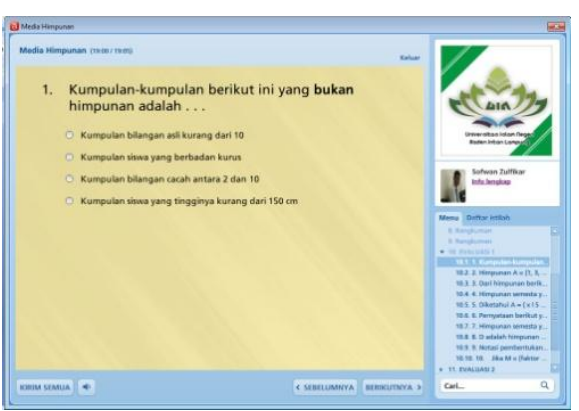

Gambar 7. Soal Evaluasi 
B. Hasil Uji Peningkatan Pemahaman Konsep

Tahapan selanjutnya untuk mengetahui seberapa besar efektifitas penggunaan produk didapatkan dari hasil ujicoba pemakaian produk yang dilakukan terhadap 24 peserta didik di SMPN 1 Rajabasa, Lampung Selatan.

Diakhir pembelajaran dialukan penilaian berdasarkan soal evaluasi yang terdapat di media pembelajaran. Setelah dianalisis dengan uji t satu pihak didapatkan bahwa memang benar hasil penilaian akhir peserta didik rata-rata lebih dari 75 yang menjadi standar KKM. Berdsarkan hasil penilaian akhir, didapatkan bahwa 19 orang peserta didik medapatkan nilai sesuai atau lebih dari KKM yang di tentukan, 5 orang peserta didik masih mendapatkan nilai dibawah KKM. Dengan demikian produk dikategorikan efektif sebagi media pembelajaran dengan 79,17\% peserta didik dinyatakan lulus KKM. Hasil ini sejalan dengan pernyataan Candra Utami yang mengatakan bahwa pembelajaran dengan implementasi media Articulate Studio terlaksana dengan sangat baik, aktivitas siswa tergolong baik, hasil belajar siswa meningkat dan siswa memberikan respon positif terhadap media pembelajaran Articulate Studio dan implementasinya hasil(Mashfufah 2016).

Berdasarkan penelitian yang telah dilakukan, produk hasil pengembangan ini memiliki beberapa kelebihan diantaranya : (1) Mampu menyajikan materi pembelajaran dengan menampilkan video, tentang konsep yang dipelajari sehingga memudahkan siswa memahami pelajaran; (2) Memiliki tampilan visual yang baik dan menarik; (3) Dilengkapi dengan evaluasi yang menyajikan soal-soal secara interaktif dan beragam sehingga membantu siswa menguji kemampuan dan evaluasi secara mandiri; dan (4) Media ini sangat praktis karena berupa softwere komputer yang bisa disimpan dalam sebuah compact disk ataupun alat penyimpanan yang lain.

Produk ini juga masih memiliki beberapa kelemahan yang masih perlu diperbaiki, kelemahan dari produk hasil pengembangan ini antara lain : (1) Masih minimnya refrensi untuk mempelajari penggunaan Articulate Studio13; (2) Produk ini hanya dapat digunakan pada materi himpunan.

\section{Kesimpulan}

Berdasarkan hasil dan pembahasan dapat disimpulkan bahwa: 1) Penelitian ini menghasilkan produk berupa media Articulate Studio'13 pada pembelajaran matematika materi himpunan; 2) Kelayakan menurut para ahli yaitu sangat layak dari hasil validasi pada format materi dengan persentase skor rata-rata $88.3 \%$ persentase ahli media, 86,1\%;3) Respon peserta didik terhadap kemenarikan produk sangat menarik dengan persentase rata-rata dalam skala kecil dan skala luas masing- masing diperoleh skor rata-rata yakni $77 \%$ dan $80 \%$; 4) media pebelajaran dinyatakn efektif dengan persentasi 79,17\% peserta didik lulus KKM.

\section{Saran}

Penelitian dan pengembangan media pembelajaran Articulate Studio'13 dalam pembelajaran matematika materi himpunan perlu ditindak lanjuti lagi untuk penelitian dibidang pengembangan bahan ajar yang lebih baik lagi dan perlu dikembangkan lebih lanjut.

\section{Ucapan Terimakasih}

Ucapan terimakasih disampaikan kepada Program Studi Pendidikan Matematika (PSPM) UIN Raden Intan Lampung serta semua pihak yang sudah membantu peneliti dalam menyelesaikan penelitian ini.

\section{Daftar Pustaka}

Achadiyah, Rendik Uji Chandra Rolisca dan Bety Nur. "Pengembangan Media Evaluasi Pembelajaran Dalam Bentuk Online Berbasis E-Learning Menggunakan Software Wondershare Quiz Creator Dalam Mata Pelajaran Akuntansi SMA Brawijaya Smart School (Bss)." Jurnal Pendidikan Akuntansi Indonesia XII: 42.

Anggoro, Bambang Sri. 2015. "Pengembangan Modul Matematika Dengan Strategi Problem 
Solving Untuk Mengukur Tingkat Kemampuan Berpikir Kreatif Matematis Siswa." Al-Jabar : Jurnal Pendidikan Matematika 6(2): 122-29.

Farida. 2015. "Mengembangkan Kemampuan Pemahaman Konsep Peserta Didik Melalui Pembelajaran Berbasis VCD.” Al-Jabar : Jurnal Pendidikan Matematika 6(1): 25-32.

Fataturrohmah, Anis, and R Masykur. 2017. "PENGARUH MODEL CINTA BERBANTU MEDIA TANGRAM."

Irwandani, Irwandani et al. 2017. "Modul Digitallinteraktif Berbasis Articulate Studio'13 : Pengembangan Pada Materi Gerak Melingkar Kelas X." Jurnal Ilmiah Pendidikan Fisika AlBiruni 6(2): 221-31.

Lee, Alice Y L. 2016. "Media Education in the School 2.0 Era: Teaching Media Literacy through Laptop Computers and iPads." Global Media and China 1(4): 435 -449.

Mashfufah, Candra Utama dan Aynin. 2016. "Implementasi Media Pembelajaran Articulate Studio Untuk Meningkatkan Hasil Belajar Siswa.” Jurnal Pena Sains 3(1).

Masykur, Rubhan, ; Nofrizal, and ; Muhamad Syazali. 2017. "Pengembangan Media Pembelajaran Matematika Dengan Macromedia Flash.” Jurnal Pendidikan Matematika 8(2): 177-86.

Navarro-ibarra, Lizzeth Aurora, Omar Cuevas, and Julia Xochitl. 2017. “Teaching-Learning Mathematics in a Virtual Environment . Empirical Evidence in Scenarios of Higher Education." IEJME-Mathematics Education 12(4): 397-408.

Pardimin, and Sri Adi Widodo. 2017. "Development Comic Based Problem Solving in Geometry." Iejme - Mathematics Education 12(3): 233-41.

Syazali, Muhamad. 2015. "Pengaruh Model Pembelajaran Creative Problem Solving Berbantuan Maple II Terhadap Kemampuan Pemecahan Masalah Matematis.” Al-Jabar:Jurnal Pendidikan Matematika 6(1): 91-98.

Wijayanti, Septiana, and Joko Sungkono. 2017. "Pengembangan Perangkat Pembelajaran Mengacu Model Creative Problem Solving Berbasis Somatic, Auditory, Visualization, Intellectually." Jurnal Al-Jabar 8(2): 101-10. 